\title{
PENERAPAN MODEL PEMBELAJARAN KOOPERATIF TIPE STUDENT TEAM ACHIEVEMENT DIVISION UNTUK MENINGKATKAN MOTIVASI DAN PRESTASI BELAJAR ILMU GIZI SISWA
}

\author{
Ni Made Muliartini \\ SMK Negeri 2 Singaraja \\ Email: muliartini@gmail.com
}

\begin{abstract}
ABSTRAK
Tujuan dari penelitian ini adalah untuk mengetahui peningkatan motivasi dan prestasi belajar ilmu gizi siswa kelas X Tata Boga 3 SMK Negeri 2 Singaraja tahun pelajaran 2016/2017 setelah diterapkannya model pembelajaran kooperatif tipe Student Team Achievement Division. Penelitian ini adalah penelitian tindakan kelas. Subjek dalam penelitian ini adalah siswa kelas $X$ tata boga 3 SMK N 2 Singaraja tahun pelajaran 2016/2017 yang berjumlah 40 orang. Sedangkan objeknya adalah motivasi dan prestasi belajar siswa. Data motivasi belajar siswa dikumpulkan dengan lembar kuesioner, sedangkan data prestasi belajar siswa dikumpulkan dengan tes pilihan ganda. Analisis data yang digunakan pada penelitian ini menggunakan analisis data deskriptif. Berdasarkan penelitian yang telah dilakukan dapat disimpulkan bahwa penerapan model kooperatif tipe Student Team Achievement Division dapat meningkatkan motivasi dan hasil belajar siswa kelas X tata boga 3 SMK Negeri 2 Singaraja tahun pelajaran 2016/2017. Hal ini dapat dilihat dari nilai rata-rata motivasi belajar siklus I sebesar 52.62 dan 58.5 yang berkatagori positif pada siklus II. Untuk rata- rata hasil belajarpada siklus I sebesar 72.25, Pada siklus II menjadi sebesar 80.12 .
\end{abstract}

Kata kunci: prestasi belajar, model pembelajaran kooperatif tipe student team achievement division, motivasi belajar.

\begin{abstract}
The purpose of this study was to determine the increase in motivation and achievement of learning nutritional science students of class X Tata Boga 3 SMK Negeri 2 Singaraja in the academic year 2016/2017 after the implementation of the cooperative learning model type Student Team Achievement Division. This research is a classroom action research. The subjects in this study were class X cook 33 Singaraja N 2 Vocational High School 2016/2017 academic year totaling 40 people. While the object is motivation and student achievement. Data on student learning motivation was collected by questionnaire sheets, while data on student achievement was collected by multiple choice tests. Data analysis used in this study used descriptive data analysis. Based on the research that has been done, it can be concluded that the application of the cooperative model of the Student Team Achievement Division can increase the motivation and learning outcomes of class $\mathrm{X}$ culinary 3 at SMK Negeri 2 Singaraja in the academic year 2016/2017. This can be seen from the average value of learning motivation in the first cycle of 52.62 and 58.5 which was positively categorized in cycle II. For the average learning outcomes in the first cycle of 72.25 , the second cycle becomes 80.12 .
\end{abstract}

Keywords: learning achievement, cooperative learning model student team achievement division type, learning motivation. 


\section{PENDAHULUAN}

Dewasa ini, pemerintah sedang gencar-gencarnya melakukan upaya peningkatan mutu pendidikan. Salah satu upaya yang dilakukan pemerintah adalah dengan menyempurnakan kurikulum yang berlaku dalam dunia pendidikan.Kurikulum 2013 pun sudah dikembangkan dan dilaksanakan sebagai penyempurnaan kurikulum KTSP. Tujuannya untuk menyiapkan generasi muda Indonesia yang siap dalam kompetensi sikap, keterampilan, dan pengetahuan.

Kegiatan pembelajaran pada kurikulum 2013 diharapkan untuk membentuk watak, membangun pengetahuan, sikap dan kebiasaan-kebiasaan untuk meningkatkan mutu kehidupan peserta didik. Kegiatan pembelajaran diharapkan mampu memberdayakan semua potensi peserta didik untuk menguasai kompetensi yang diharapkan. Pemberdayaan diarahkan untuk mendorong pencapaian kompetensi dan perilaku khusus supaya setiap individu mampu menjadi pembelajar sepanjang hayat dan mewujudkan masyarakat belajar.

Kegiatan pembelajaran perlu menggunakan prinsip yang: (1) berpusat pada peserta didik, (2) mengembangkan kreativitas peserta didik, (3) menciptakan kondisi menyenangkan dan menantang, (4) bermuatan nilai, etika, estetika, logika, dan kinestetika, dan (5) menyediakan pengalaman belajar yang beragam

Model pembelajaran yang dirasa sesuai dengan prinsip pembelajaran tersebut adalah model pembelajaran kooperatif tipe STAD (Student Team Achievement Division). Pembelajaran kooperatif merupakan model pembelajaran dimana siswa belajar dalam kelompok-kelompok kecil yang memiliki tingkat kemampuan yang berbeda. Model pembelajaran kooperatif berbeda dengan sekedar belajar dalam kelompok, perbedaan ini terletak pada adanya unsur-unsur dasar dalam pembelajaran kooperatif yang tidak ditemui dalam pembelajaran kelompok yang dilakukan asal-asalan. Prosedur model pembelajaran koopertatif yang dilakukan dengan benar akan memungkinkan guru dapat mengelola kelas dengan lebih efektif dan efisien.

STAD (Student Team Achievement Division) ini dikembangkan oleh Slavin (2010) yang merupakan salah satu tipe cooperative learning yang menekankan interakssi diantara siswa untuk saling memotivasi dan saling membantudalam menguasai materi dan pencapaian prestasi secara maksimal, danjuga merupakan salah satu metode atau pendekatan dalam pembelajarankooperatif yang sederhana dan baik untuk guru yang baru mulai menggunakan pendekatan kooperatif dalam kelas, STAD juga merupakan suatu metode pembelajaran kooperatif yang efektif. Gagasan utama STAD adalah untuk memotivasi siswa supaya dapatsaling mendukung dan membantu satu sama lain dalam menguasi pengetahuan yang diajarkan oleh guru. Jika para siswa ingin agar timnyamendapatkan penghargaan tim, mereka harus membantu teman satu timnya untuk mempelajari materinya (Slavin: 2010).

Setelah mengetahui keunggulan model STAD (Student Team Achievement Division) rasanya sangat cocok diterapkan di kelas X tata boga 3 SMK Negeri 2 Singaraja. Berdasarkan hasil observasi terhadap proses pembelajaran dan wawancara dengan siswa yang sekaligus dengan pemberian angket, terungkap beberapa permasalahan yang dapat diidentifikasi adalah sebagai berikut.

Pertama, berdasarkan angket yang disebarkan kepada siswa serta dari hasil observasi dikelas, 18 orang siswa menyatakan kurang menyiapkan diri untuk mengikuti pembelajaran di kelas walaupun mereka sudah mengetahui materi yang akan diajarkan oleh guru di kelas. Kedua, dalam proses pembelajaran motivasi siswa untuk belajar masih rendah, dan siswa cenderung pasif. Rendahnya aktivitas siswa untuk belajar ditunjukkan dari kurangnya perhatian siswa dalam kegiatan pembelajaran, masih sedikit anak yang memberikan tanggapan ketika guru menyampaikan suatu pertanyaan mengenai materi yang dipelajari. Hal ini telah disadari 
oleh guru, sehingga guru mencoba meningkatkan motivasi siswa melalui metode demonstrasi, serta menggunakan media simulasi. Akan tetapi upaya ini belum mampu meningkatkan motivasi siswa, malahan siswa hanya terpaku melihat simulasi yang ditampilkan oleh guru, sehingga pembelajarannya menjadi kurang efektif.

Dengan menerapkan model pembelajaran kooperatif tipe STAD (Student Team Achievement Division) diharapkan mampu mengatasi permasalahan tersebut. Siswa menjadi lebih termotivasi dan aktif dalam mengikuti pelajaran, sehingga nantinya berpengaruh terhadap hasil belajar siswa.

Berdasarkan uraian di atas dapat dikatakan bahwa tercapainya tujuan pembelajaran terutama untuk peningkatan hasil belajar dapat dipengaruhi oleh model pembelajaran yang diterapkan pada proses pembelajaran serta motivasi siswa dalam memperjelas tujuan belajar. Maka dalam penelitian ini, akan dikaji lebih dalam tentang Penerapan Model Pembelajaran Kooperatif Tipe Student Team Achievement Division untuk Meningkatkan Motivasi dan Prestasi Belajar Ilmu Gizi Siswa Kelas X Tata Boga 3 SMK Negeri 2 Singaraja Tahun Pelajaran 2016/2017.

Tujuan penelitian ini adalah sebagai berikut.

1. Meningkatkan motivasi belajar ilmu gizi siswa kelas X Tata Boga 3 SMK Negeri 2 Singaraja Tahun Pelajaran 2016/2017 melalui penerapan model pembelajaran kooperatif tipe Student Team Achievement Division.

Meningkatkan prestasi belajar Ilmu Gizi siswa kelas X Tata Boga 3 SMK Negeri 2 Singaraja Tahun Pelajaran 2016/2017 melalui penerapan model pembelajaran kooperatif tipe Student Team Achievement Division.

\section{METODE PENELITIAN}

Penelitian ini menggunakan desain penelitian tindakan kelas (classroom action research) yang secara umum bertujuan untuk meningkatkan motivasi dan prestasi belajar siswa kelas X tata boga 3 SMK N 2 Singaraja tahun pelajaran 2016/2017. Penelitian ini dilaksanakan dalam dua siklus. Setiap siklus terdiri dari empat tahapan yaitu perencanaan tindakan, pelaksanaan tindakan, observsi/evaluasi, dan refleksi. Siklus I terdiri,dua kali pertemuan untuk membahas materi peranan makanan bagi tubuh manusia (RPP 01 dan RPP 02), 1 kali pertemuan untuk tes akhir siklus. Siklus II terdiri dari 2 kali pertemuan untuk membahas materi menu seimbang (RPP 03 dan RPP 04), 1 kali pertemuan tes akhir siklus.

Penelitian ini akan dilaksanakan dalam waktu 3 bulan yaitu dari bulan februari 2017 sampai bulan april 2017. Observasi awal dilakukan sebelum pelaksanaan penelitian, yang bertujuan untuk mengidentifikasi permasalahan yang terdapat di Kelas X tata boga 3 SMK Negeri 2 Singaraja Tahun Pelajaran 2016/2017.

Subjek dalam penelitian ini adalah siswa kelas $\mathrm{X}$ tata boga 3 SMK N 2 Singaraja tahun pelajaran 2016/2017 yang berjumlah 40 orang. Objek penelitian tindakan kelas yang dilakukan terhadap subjek penelitian di kelasX tata boga 3 SMK N 2 adalah 1) motivasi belajar, dan 2) prestasi belajar siswa.

Penelitian tindakan kelas ini terdiri dari dua siklus. Dalam setiap siklus dibagi menjadi 4 tahap kegiatan yaitu, (1) perencanaan, (2) tindakan, observasi/evaluasi, dan (4) refleksi. Adapun alur penelitiannya dapat disajikan seperti Gambar 1. 


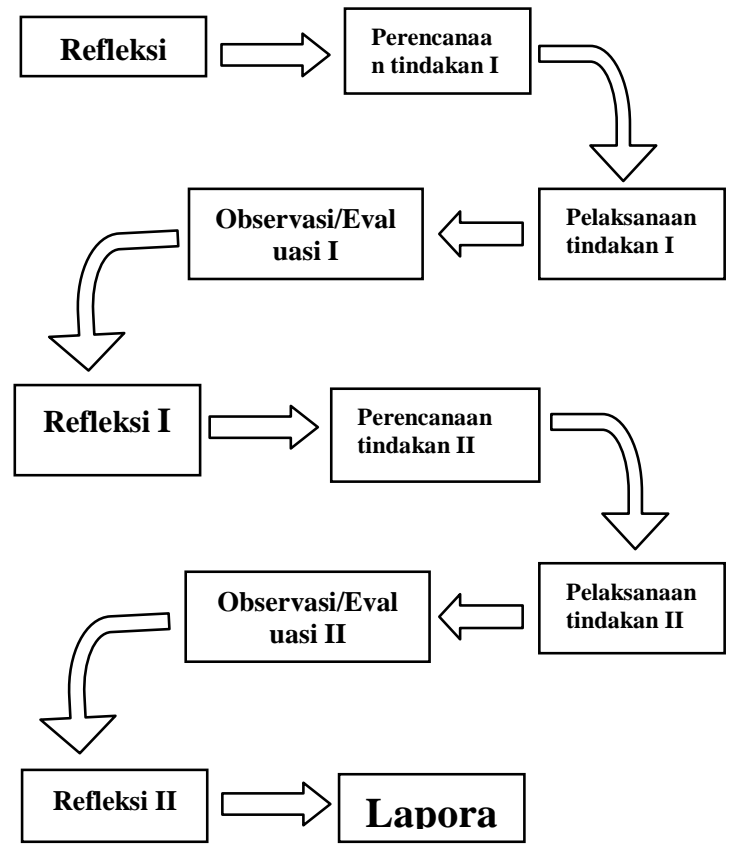

Gambar 1. Alur Pelaksanaan Tindakan Kelas Dua Siklus

(Diadaptasi dari Kemmis dan Taggart dalam Sukardi, 2003)

\section{A. Refleksi Awal}

Sebelum melakukan penelitian, peneliti mengadakan refleksi awal untuk mengidentifikasi permasalahan serta keluhan yang dialami oleh siswa kelas $\mathrm{X}$ tata boga 3 SMK N 2 Singaraja tahun pelajaran 2016/2017. Berdasarkan hasil pengamatan teridentifikasi masalah adalah sebagai berikut, (1) jalannya pembelajaran masih teacher centered, (2) model pembelajaran yang diterapkan oleh guru belum mampu mengatasi masalah yang ditemukan, (3) siswa masih belum siap mengikuti pembelajaran, (4) siswa kurang termotivasi mengikuti pembelajaranyang menyebabkan siswa merasa bosan dalam mengikuti pembelajaran sehingga berdampak pada hasil belajar siswa.

Sebagai tindak lanjut dari solusi yang dikemukakan oleh peneliti, maka peneliti mengimplementasikan langsung model kooperatif tipe Student Team Achievement Divisionmelalui penelitian tindakan kelas (classroomresearch), di kelas $\mathrm{X}$ tata boga 3 SMK N 2 Singaraja tahun pelajaran 2016/2017dalam pembelajaran ilmu gizi. Penelitian tindakan kelas ini dilaksanakan dalam dua siklus.
B. Siklus 1

Sesuai dengan siklus yang ditetapkan seperti gambar 3.1, maka tahapan-tahapan pelaksanaan penelitian tindakan ini adalah sebagai berikut.

1) Tahap perencanaan tindakan 1

Pada tahap ini disusun rancangan tindakan sebagai acuan dalam pelaksanaan tindakan sebagai berikut.

1) Menjabarkan materi pembelajaran menjadi sub-sub materi sesuai dengan pedoman silabus.

2) Merumuskan indikator hasil belajar, sebagai pembatasan tentang apa yang diharapkan dapat dipahami siswa setelah mengikuti pembelajaran yang didasarkan pada standar kompetensi mata pelajaran.

3) Menyusun rencana pelaksanaan pembelajaran (RPP)

4) Merancang instrumen perangkat pembelajaran seperti Lembar Kerja Siswa (LKS), tugas-tugas terstruktur, tes kognitif akhir siklus,

5) Membentuk kelompok siswa yang beranggotakan 4-5 orang.

6) Menyiapkan kunci jawaban semua tes yang akan digunakan dalam penilaian.

7) Sebelum pelaksanaan tindakan 1 dilakukan orientasi awal dan pengenalan terhadap rencana implementasi pendekatan keterampilan proses dalam pembelajaran.

2. Tahap pelaksanaan tindakan 1

Tindakan pada siklus I dilaksanakan dalam 2 kali pertemuan. Langkah-langkah yang dilakukan adalah sebagai berkut.

Pertemuan I/Siklus I

1) Kegiatan Pendahuluan

(1) Mengkondisikan kelas dalam situasi yang kondusif untuk belajar.

(2) Mengorganisasikan siswa ke dalam kelompoknya masing-masing.

(3) Memberikan motivasi dan apersepsi kepada siswa.

(4) Menyampaikan kompetensi dasar dan indikator pencapaian

2) Kegiatan Inti

(1) Mengajukan permasalahan pada siswa dengan membagikan LKS. 
(2) Memberi kesempatan kepada masingmasing kelompok untuk melakukan diskusi, mengerjakan LKS, dan berdiskusi antar anggotanya.

(3) Membimbing kelompok dalam bekerja dan belajar sekaligus mengobservasi aktivitas belajar siswa dalam kegiatan pembelajaran.

(4) Melakukan diskusi kelas untuk memastikan bahwa mereka telah mengetahui jawaban yang benar.

3) Kegiatan Akhir

(1) Mengajak peserta didik untuk menyimpulkan materi yang telah diajarkan.

(2) Melaksanakan tindak lanjut pembelajaran dengan pemberian tugas atau latihan yang harus dikerjakan di rumah, menjelaskan kembali bahan yang dianggap sulit oleh peserta didik, membaca materi pelajaran tertentu, memberikan motivasi atau bimbingan belajar.

(3) Mengemukakan topik yang akan dibahas pada pertemuan selanjutnya.

(4) Memberikan evaluasi lisan atau tertulis

Pertemuan II / Siklus I

Pada pertemuan II siklus I, kegiatan yang dilakukan adalah sama seperti pada pertemuan I siklus I hanya materi yang disampaikan berbeda dalam RPP 02 . Kegiatan ini dilakukan selama 5 jam pelajaran yaitu 225 menit.

Pertemuan III/ Siklus I

Pada pertemuan III siklus I hanya diadakan tes hasil belajar dalam bentuk 20 butir tes pilihan ganda untuk seluruh siswa kelas X tata boga 3 SMK N 2 Singaraja yang dilakukan selama 5 Jam Pelajaran (JP) yaitu 225 menit.

\section{Tahap Observasi/Evaluasi I}

Dalam mengobservasi siswa,hal-hal yang diobservasi adalah sebagai berikut.

1) Mengobservasi kemampuan siswa dalam pelajaran saat melakukan diskusi di kelas dengan menggunakan lembar observasi kompetensi pada tiap pertemuan.

2) Mengevaluasi hasil belajar siswa berdasarkan hasil LKS dan kuis pada akhir pembelajaran serta tes hasil belajar yang diberikan pada akhir siklus I.

3) Mencatat fenomena yang diamati baik berupa kendala-kendala yang ditemukan selama pelaksanaan tindakan.

\section{Refleksi I}

Refleksi dilakukan pada setiap akhir pembelajaran dan akhir siklus. Sebagai dasar refleksi pada setiap akhir pembelajaran adalah kendala-kendala yang dialami siswa dalam pembelajaran ilmu gizi melalui model model kooperatif tipe Student Team Achievement Division. Refleksi dilakukan oleh peneliti untuk melihat kekurangan dan kelebihan setiap tindakan yang diberikan pada siklus I. Hasil-hasil refleksi tersebut selanjutnya digunakan sebagai bahan pertimbangan atau penyempurnaan tahapantahapan pada siklus II.

Data yang dikumpulkan dalam penelitian ini adalah data motivasi belajar dan prestasi belajar siswa. Data motivasi belajar siswa dikumpulkan dengan lembar kuesioner, sedangkan data prestasi belajar siswa dikumpulkan dengan tes pilihan ganda. Setelah data terkumpul, data tersebut dianalisis secara deskriptif.

Untuk menetapkan keberhasilan tindakan yang dilaksanakan, penetapan Kriteria atau indikator keberhasilan mutlak diperlukan. Kriteria atau indikator keberhasilan ditetapkan sebagai berikut.

a. Kriteria keberhasilan untuk motivasi belajar siswa adalah jika dari analisis diperoleh hasil minimal positif.

b. Hasil belajar siswa dikatakan berhasil secara individual apabila telah memperoleh nilai $\geq 67.00$ dengan nilai konversi 2,67 predikat B.

\section{HASIL DAN PEMBAHASAN Hasil Penelitian}

Secara umum, pelaksanaan pembelajaran didalam kelas selama penelitian telah berlangsung sesuai dengan rencana pelaksanaan pembelajaran yang telah disusun. Penelitian ini dilaksanakan dalam dua siklus, yang dilaksanakan di SMK Negeri 2 Singaraja, Kabupaten Buleleng Tahun Pelajaran 2016/2017. Subjek dalam penelitian ini sebanyak 40 orang siswa. Pada awal kegiatan, peneliti 
yang bertindak sebagai guru menyampaikan kepada siswa bahwa kegiatan pembelajaran ilmu gizi untuk pokok bahasan giziakan dilaksanakan dengan menerapkan model pembelajaranmodel kooperatif tipe Student Team Achievement Division.

Peneliti menggunakan waktu kurang lebih 15 menit pada pertemuan pertama untuk mensosialisasikan atau memberikan gambaran kepada siswa mengenai model pembelajaran yang akan diterapkan selama pembelajaran kedepannya. Pada kesempatan ini guru menyampaikan bahwa dalam setiap pembelajaran akan diberikan LKS maupun kuis diakhir pembelajaran pada setiap pertemuan dengan tujuan dapat meningkatkan pemahaman siswa.

Pada siklus I, skor motivasi belajar siswa setelah penerapan model model kooperatif tipe Student Team Achievement Division adalah sebesar 2105 dan rataratanya sebesar 52.62 yang berkatagori positif. Sedangkan hasil belajar siswa pada siklus I diperoleh data sebagai berikut: sebanyak 27 orang siswa atau $67.5 \%$ dinyatakan tuntas, dan sisanya yaitu 13 orang siswa atau $32.5 \%$ telah dinyatakan belum memenuhi standar ketuntasan. Dengan demikian ketuntasan hasil belajar siswa pada siklus I baru mencapai $67.5 \%$.

Berdasarkan hasil observasi pada siklus I terungkap beberapa kendala dan hambatan yang dijadikan sebagai refleksi untuk siklus II terkait dengan proses pembelajaran model kooperatif tipe Student Team Achievement Divisionyang diterapkan di kelas $\mathrm{X}$ tata boga 3SMK $\mathrm{N} 2$ Singarajauntuk pokok bahasan gizi, yaitu sebagai berikut.

1) Untuk motivasi belajar siswa sudah cukup positif, hal ini terjadi karena siswa sudah mulai menyukai model pembelajaran kooperatif tipe Student Team Achievement Division.

2) Namun proses pembelajaran pada siklus I secara umum belum dapat berjalan secara optimal. Hal ini disebabkan karena masih ada siswa yang masih terbiasa dengan pola pembelajaransebelumnya yaitu siswa hanya duduk mendengarkan penjelasan dari penelitiatau belajar berkelompok tapi hasil diskusi kelompoknya tidak dibahas oleh kelompok yang lainnya.

3) Dalam diskusi kelompok maupun kelas, siswa kurang aktif dalam mengemukakan pendapat dan hanya mengandalkan pendapat teman yang pintar dari kelompoknya.

4) Siswa masih kurang aktif untuk mengajukan pendapat dari permasalahan yang disajikan oleh peneliti pada awal pembelajaran maupun selama proses pembelajaran berlangsung. Kebanyakan pendapat siswa muncul dari beberapa siswa yang monoton itu saja.

5) Berdasarkan hasil akhir tes hasil belajar pada siklus I, terungkap bahwa siswa belum mampu menyelesaikan permasalahan yang diberikan secara terstruktur, siswa masih asal-asalan dalam menjawab soal.

Berdasarkan temuan dari kegiatan observasi yang dilakukan selama pelaksanaan tindakan I, maka diadakan upaya untuk memperbaiki proses tindakan pada siklus berikutnya, yaitu sebagai berikut.

1) Meningkatkan lagi motivasi belajar siswa

2) Memberikan kesempatan lebih banyak pada siswa untuk bertanya dan mengajukan pendapat mengenai materi yang dibahas selama proses pembelajaran berlangsung.

3) Menunjuk siswa-siswa yang kurang aktif dalam berpendapat untuk mencoba mengajukan pendapatnya agar siswa tersebut menjadi lebih berani mengungkapkan pendapatnya.

4) Membimbing dan memantau siswa secara lebih intensif, agar kegiatan diskusi kelas tidak didominasi oleh siswa-siswa tertentu saja.

Melihat hasil refleksi siklus I di atas, maka siklus dilanjukan ke siklus II. Pada siklus II motivasi belajar siswa setelah penerapan model kooperatif tipe Student Team Achievement Division adalah sebesar 2340 dan rata- ratanya sebesar 58.5 yang berkatagori positif. Sedangkan hasil belajar 
siswa pada siklus II diperoleh data sebagai berikut: sebanyak 37 orang siswa atau $92.5 \%$ dinyatakan tuntas, dan sisanya yaitu 3 orang siswa atau $7.5 \%$ telah dinyatakan belum memenuhi standar ketuntasan. Dengan demikian ketuntasan hasil belajar siswa pada siklus II sudah sesuai dengan kriteria yang ditentukan.

Melalui perbaikan proses pembelajaran pada pelaksanakan siklus I, maka pelaksanakan proses pembelajaran pada siklus II telah nampak adanya peningkatan proses pembelajaran siswa. Adapun temuan-temuan yang diperoleh selama tindakan pelaksanakan siklus II, yaitu sebagai berikut.

1) Motivasi siswa dalam mengikuti pembelajaran sudah meningkat bahkan ada yang berkatagori sangat positif.

2) Kondisi dan situasi belajar siswa pada setiap pertemuan menunjukkan situasi belajar yang lebih kondusif, jika dibandingkan dengan pertemuanpertemuan sebelumnya pada siklus I. Siswa sudah mulai terbiasa dengan penerapan model pembelajaran yang menuntut aktivitas tinggi seperti mau untuk mengajukan pendapat. Pada siklus II, tampak bahwa siswa sudah bisa memberikan penjelasan kepada temannya yang masih salah dengan menggunakan bahasa pergaulan sehari-hari.

3) Dominasi siswa-siswa yang lebih mengerti sudah mulai berkurang. Siswa-siswa tersebut sudah mau memberi kesempatan kepada rekanrekannya untuk mengajukan pendapat, serta memberi penjelasan apabila rekannya tersebut mengalami kekeliruan, walaupun dengan bahasa pergaulan sehari-hari.

Pada tes akhir siklus II, terjadi peningkatan terhadap kualitas alasan-alasan yang dibuat oleh siswa dari permasalahan yang diberikan.

Perbandingan motivasi dan prestasi belajar pada siklus I dan siklus II disajikan dalam diagram berikut.

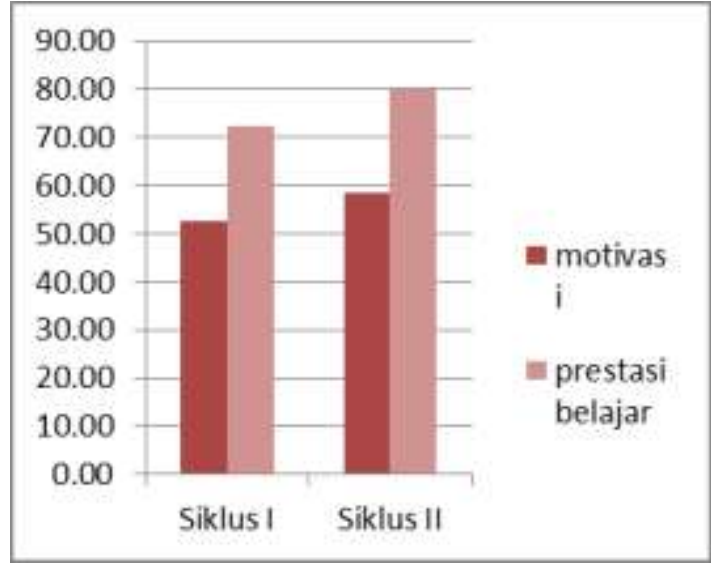

Gambar 2. Perbandingan Motivasi Belajar dan Prestasi Belajar Siklus I dan Siklus II

Berdasarkan hasil penelitian yang telah dilaksanakan selama dua siklus menunjukkan adanya peningkatan terhadap motivasi belajar dan hasil belajar siswa, melalui penerapan model kooperatif tipe Student Team Achievement Division dalam pembelajaran ilmu gizi di kelas $\mathrm{X}$ tata boga 3 SMK Negeri 2 Singaraja tahun pelajaran 2016/2017.

\section{Pembahasan Hasil Penelitian}

Hasil penelitian yang telah dilaksanakan selama 2 siklus adalah sebagai berikut. Hasil motivasi belajar pada siklus I, 15 siswa memberikan respon cukup positif dan 25 siswa memberikan respon positif dengan rata- ratanya sebesar 52.62 yang berkatagori positif. Hasil belajar siklus I nilai rata-rata yang diperoleh adalah 72.25 dan standar deviasi 8.840, sebanyak 27 orang siswa atau $67.5 \%$ dinyatakan tuntas, dan sisanya yaitu 13 orang siswa atau $32.5 \%$ telah dinyatakan belum memenuhi standar ketuntasan. Dalam proses pelaksanaan siklus I masih belum optimal, hal ini disebabkan beberapa (refleksi siklus 1) Berdasarkan hasil refleksi siklus I, maka pelaksanaan tindakan pada siklus II mengacu pada perbaikan-perbaikan untuk meminimalisasi faktor penyebab belum optimalnya pembelajaran pada siklus I.

Berdasarkan perbaikan yang telah dilakukan, motivasi belajar pada siklus II dan hasil pembelajaran yang diperoleh pada siklus II ini menunjukkan adanya peningkatan. Hasil pembelajaran tersebut terlihat dari motivasi belajar $6 r$ siswa 
memberikan respon cukup positif, 32 siswa memberikan respon positif dan 2 siswa memberikan respon sangat positif dan ratarata motivasi belajar diperoleh sebesar 58.5 yang berkatagori positif. Untuk hasil belajar nilai rata-rata hasil belajar pada siklus II diperoleh sebesar 80.12 dan standar deviasi 7.552. Sebanyak 37 orang siswa atau $92.5 \%$ dinyatakan tuntas, dan sisanya yaitu 3 orang siswa atau $7.5 \%$ telah dinyatakan belum memenuhi standar ketuntasan Berdasarkan kegiatan siklus I dan II terjadi peningkatan hasil belajar. Siswa menyatakan senang dan lebih tertantang untuk belajar ilmu gizi dengan menggunakan model kooperatif tipe Student Team Achievement Division. Hal ini dikarenakan siswa menggunakan segenap kemampuan berpikirnya dan melatih siswa untuk berani tampil mengemukakan bertanya, menjawab, dan pendapat mereka.

Penelitian ini relevan dengan penelitian yang dilakukan oleh Putra (2013) yang menyatakan bahwa model pembelajaran kooperatif tipe STAD berpengaruh terhadap hasil belajar matematika siswa kelas V SD Gugus Ubud Tahun Ajaran 2012/2013. Hal tersebut terjadi karena model STAD dapat membantu dan memotivasi semangat untuk berhasil bersama.

Berdasarkan uraian hasil pennelitian diperoleh adanya hasil yang baik terhadap penerapan model kooperatif tipe Student Team Achievement Division sebagai upaya meningkatkan motivasi dan hasil belajar siswa kelas $\mathrm{X}$ tata boga 3SMK Negeri 2 Singaraja tahun pelajaran 2016/2017. Hal ini terjadi karena penerapan model ini menyediakan suasana yang kondusif dalam pembelajaran. Siswa memiliki kesempatan untuk mengalami sendiri, berkreativitas untuk mengembangkan aspek-aspek berpikir mereka dalam pembelajaran.

\section{PENUTUP}

Simpulan

Berdasarkan hasil penelitian dan pembahasan yang telah diuraikan sebelumnya, dapat disimpulkan bahwa penerapan model kooperatif tipe Student Team Achievement Division dapat meningkatkan motivasi dan hasil belajar siswa kelas $\mathrm{X}$ tata boga $3 \mathrm{SMK}$ Negeri 2 Singaraja tahun pelajaran 2016/2017. Hal ini dapat dilihat dari nilai rata-rata motivasi belajar siklus I sebesar 52.62 dan 58.5 yang berkatagori positif pada siklus II. Untuk rata- rata hasil belajarpada siklus I sebesar 72.25, Pada siklus II menjadi sebesar 80.12.

\section{Saran}

Dalam menerapkan model kooperatif tipe Student Team Achievement Division, adapun hal-hal yang disarankan kepada guru maupun peneliti lain adalah untuk lebih mengoptimalkan kemampuan siswa dalam pembelajaran, guru harus mengupayakan pembelajaran ke arah pembelajaran yang lebih menekankan kepada student center. Setiap anak itu hebat, tugas guru adalah mengenali dan memfasilitasi anak tersebut.

\section{DAFTAR PUSKATA}

A.M, Sardiman. 2007. Interaksi dan Motuvasi Belajar Mengajar. Jakarta: RajaGravindo Persada

Arikunto, Suharsimi. 2002. Prosudur Penelitian Suatu Pendekatan Prektek.Jakarta: Bumi Aksara.

Depdiknas, 2003. Pengembangan Kurikulum dan Sistem Penilaian Berbasis Kompetensi. Jakarta : Direktorat Jendral Pendidikan Dasar dan Menengah, Diretorat Pendidikan Lanjutan Pertama.

Indrawati, Ni Luh Gede Eka. 2017. "Penerapan Model Pembelajaran Kooperatif Tipe Student Team Achievement Divisions (Stad) Untuk Meningkatkan Hasil Belajar Matematika Siswa Kelas VI SD No. 1 Sading Kecamatan Mengwi Kabupaten Badung Semester I Tahun Pelajaran 2016/2017”. Journal of Education Action Research Vol 1, No 2 (2017): August 2017.

Jayano,Dw. Md. R. Dwi \& I Gst. Ngr. Japa I Md. Tegeh.2013.” Pengaruh 
Model Pembelajaran Kooperatif

Tipe Stad Bermuatan Catur

Pramana Terhadap Hasil Belajar

Matematika Kelas V Sdn 1

Sangsit”. MIMBAR PGSD

Undiksha Vol 1, No 1 (2013).

Pujiono, Rudi.2017. "Penerapan Model

Pembelajaran Kooperatif Tipe

Student Team Achievement

Divisions (Stad) Untuk

Meningkatkan Motivasi Dan Hasil

Belajar Ipa Siswa Kelas V B Sdn

047 Tarakan". Journal of Education

Research and Evaluation Vol 1, No

4 (2017).

Slavin, Robert E. 2008. Cooperative Learning. Teori, Riset, dan Praktik.Bandung: Nusa Media.

Sudana, I Putu Ari \& I Gede Astra Wesnawa.2017." Penerapan Model Pembelajaran Kooperatif Tipe STAD Untuk Meningkatkan Hasil Belajar IPA". Jurnal Ilmiah Sekolah Dasar Vol 1, No 1 (2017): Februari 2017.

Trianto. 2009. Mendesain Model Pembelajaran Inovatif-Progresif: Konsep, Landasan, dan Implementasinya pada Kurikulum Tingkat Satuan Pendidikan (KTSP). Jakarta: Kencana.

Wahyuni. 2014. "Pengaruh Penerapan Model Pembelajaran Kooperatif Tipe STAD Berbasis Interaksi Sosial Terhadap Hasil Belajar IPS Siswa Kelas V SD”. Univesitas Pendidikan Ganesha, Volume 2 